\title{
THE RED CROSS AND FAMINE RELIEF IN THE NIGER
}

Dr. de Ville de Goyet, former medical and nutritional co-ordinator for the League of Red Cross Societies in the Niger, recently wrote a paper about the famine relief programme sponsored by the Red Cross last autumn. As the action described represents a new approach to the problem of famine and to the means whereby it may be remedied, we think it worth while to reproduce this paper. ${ }^{1}$

In September 1974 some 15 delegates, recently arrived in Niamey to complete the League of Red Cross Societies' medico-nutritional teams in the Niger, met at Red Cross Society of Niger headquarters for briefing. Many National Societies were represented, including Belgium, Canada, Denmark, France, Great Britain, Norway, Sweden and Switzerland. Several veteran delegates with experience of numerous relief operations were present.

Everyone realized that the programme they were to carry out was different from the others. There was a strange ring about the phrases they heard: "vulnerable categories, prevention, evaluation, nutritional education..." "We do not distribute food systematically to the whole population..." "curative medicine must be reduced to a strict minimum".

This programme was run jointly by the Niger Government, the United Nations (mainly the FAO Office of Sahelian Relief Operations, UNICEF and WHO) and the League, which had operational responsibility. It was a pilot programme. This was made clear by the League's chief delegate who also spoke of "respecting the Government's long-term health policy in the promulgation of the programme at the community level", the only guarantee of effective action immediately and in the long-term.

\footnotetext{
${ }^{1}$ Reproduced from Contact, League-ICRC, Geneva, No. 4.
} 
The programme would not follow habits and traditions. This was a new approach to the old problem of famine relief.

Kwashiorkor and marasmus, the signs of famine, were most evident among the children and expectant and nursing mothers-those who are less able than others to look after their own needs and so form the most vulnerable groups.

\section{Helping the under-privileged}

From time immemorial, the first step in famine relief has been a food programme, i.e., distribution of free food to everyone. Where there was no strict control over those distributions, they sometimes favoured the abler groups, or inhabitants of easily accessible centres, without reaching under-privileged persons or those in isolated famine areas distant from population centres and main roads. At best, the food received kept the strongest and most productive members of the family in health, especially adults, whom most civilizations consider to have priority.

Food programmes as hitherto organized concentrated on the quantitative aspect, i.e., forwarding as much food as possible. The qualitative aspect, balanced nutrition, had been given less attention or none at all. The Niger medico-nutritional programme took a great step forward in this respect; it concentrated on vulnerable categories of the population and the nutritional qualities of the food distributed, and paid special attention to improving child nutrition and that of expectant and nursing mothers, and to improving the country's medical organization.

"Give a fish to a hungry man and you feed him for a day; teach him to catch fish and you give him food for a lifetime", says the Chinese proverb. Our field teams applied it in their medico-nutritional rehabilitation work in camps for famine victims. With an eye to ensuring long-term action, there were constant efforts to improve local public health services and to educate drought victims.

\section{Emergency action and long-term effects}

The success of the medico-nutritional programme is not to be measured in terms of tons of food distributed or hundreds of thousands of persons fed. It is to be judged by the number of children, born and unborn, whom the delegates' direct action, fairer food distribution and more balanced nourishment given by better-fed and better-educated mothers have saved from malnutrition or sickness. 
It is impossible to estimate the number of children saved from malaria by the distribution of anti-malaria tablets, or from mortal epidemics of measles by vaccination campaigns; or of nursing children who survived because their mother relieved their diarrhoea by giving them salt water to drink-after daring to flout their own cultural taboos. It is also impossible to estimate the number saved from blindness when vitamin $\mathbf{A}$ was added to their diet.

Specialized personnel had to be assembled in greater numbers than for the usual type of food distributions, in order to make a success of the pilot programme. But the investment in time and money was amply justified by the results.

One should, however, list the requirements for such success, which requirements were met in the case of Niger:

1. the authorities want nation-wide improvement in public nutrition;

2. there is already a sound basic food programme, and

3. specialized professional staff take part in planning and executing the programme at all levels.

It is encouraging to observe that the Niger medico-nutritional programme made a valid contribution to stricken communities. It also permitted the initiation of delegates into a new kind of emergency assistance which may in the future help young nations to build on a sound social and economic basis. 